\title{
EMPLOYEE RECRUITMENT AND ITS RELATIONSHIP WITH EMPLOYEE SATISFACTION: VERIFYING THE MEDIATING ROLE OF THE EMPLOYER BRAND
}

\author{
Marko Slavkovic*, Goran Pavlovic and Marijana Simic \\ Faculty of Economics, University of Kragujevac, Kragujevac, The Republic of Serbia
}

\begin{abstract}
The transformation of a capital-intensive to knowledge-driven economy has marked the beginning of a new epoch in business doing. Carrying out business activities in an extremely dynamic environment has greatly reduced the importance of traditional concepts and techniques, which is the reason why the focus has shifted to human resources and their management. Accordingly, a company should attract, retain and motivate its employees in order to ensure a high level of their satisfaction by ensuring the achievement of strategic goals. A possible direction of achieving the desired position is based on the development of the employer brand. Therefore, the aim of this paper is to determine the impact of practice in conducting employee recruitment activities on their satisfaction, as well as the influence of the employer brand as a mediator on the identified relationship between the recruitment and satisfaction of employees in Serbia. The results of the conducted empirical research study have proven the existence of a statistically significant positive influence of employee recruitment on satisfaction, while the mediating influence of the employer brand has also been fully confirmed.
\end{abstract}

Keywords: recruitment, employee satisfaction, employer brand, talents, fit model

JEL Classification: M12, M39, M51

\section{INTRODUCTION}

The digitalization of the business environment and the development of related technologies have an impact on the different aspects of business and require a rapid adaptation to emerging circumstances in order for organizations to maintain their competitive

* Correspondence to: M. Slavkovic, Faculty of Economics, University of Kragujevac, Dj. Pucara 3, 34000 Kragujevac, The Republic of Serbia; e-mail: mslavkovic@kg.ac.rs advantage. In their respective reports, well-known consulting companies and HR agencies highlight the existence of a gap in the supply of and demand for skills and human resources, and emphasize the need for a strategic approach to tackling the problem of global talent deficits. In its regular quarterly report, McKinsey states that digitalization requires an urgent change in an organization's existing behavioral patterns in the domain of the structure, strategy and capabilities of its employees, especially in the 
domain of the personalization of talent programs and the existing leadership models (McKinsey, 2018, 44). ManpowerGroup $(2018,7)$ states that the global trend of talent shortages is continuing, a 12-year maximum is expected to be reached in 2018, a lack of applicants and a lack of experience are the most common causes of the non-fulfillment of open positions, and companies with more than 250 employees are being faced with the biggest talent deficit problem. In its talent report, the Boston Consulting Group states that $57 \%$ of the participants in the conducted research study would wish work abroad, which is significantly less than in the previous survey, conducted in 2014 (Boston Consulting Group, 2018, 5). According to the leading Global Competitiveness Index (GTCI) formed on the basis of the ability of the country to attract, develop and retain talents, leading positions have been developed by high-income countries, with a high degree of correlation between the GDP per capita and the values of the GTCI (Lanvin \& Evans, 2018, 12). In addition to the evident lack of talents, these reports point to the fact that highly developed countries, currently providing the best conditions for attracting and retaining talents, will have a lesser talent inflow than those less developed because their aspirations to work abroad are being reduced. The potential causes for such a trend should be sought in the fact that an increasing number of less developed countries have been working on their own talent retention programs. The second conclusion stemming from the above reports suggests that large companies, which are dominated by multinational companies, have much more problems to fill positions than small companies and small and medium-sized enterprises, which can indirectly indicate the relatively lesser attractiveness of multinational companies as employers.

The operating arena for HR managers and HR specialists is becoming increasingly competitive with respect to the efforts companies are making to meet their talent needs in the global labor market. The simultaneous work performed by both national leaders and company leaders in attracting, developing and retaining talents is entering the zone of decreasing returns to scale, which in practice means that additional efforts do not lead to an increase in the number of applicants appearing for open positions. High-income countries and companies with a good compensation package reduce their attractiveness as a place for jobs and work because of the trend of reducing talent aspirations to work abroad, whereas the assumption of the outflow of talents from less developed countries into developed ones is taken as the key trend of the global migration. Confronted with the fact that people, intellectual capital and talents are increasingly becoming the critical factors of an organization's strategic success, and that the existing mechanisms for attracting talents do not assure the expected results, HR managers and company leaders are active in identifying the other factors that can positively influence the attraction and retention of talents. In other words, welfare and the amount of the compensation, as the material motivators, are becoming less effective in attracting talents, which is the reason why attention is increasingly being focused on the intangible factors such as employee satisfaction, the employer brand, intrinsic motivation, or a work-life balance.

Academic researchers have contributed to tackling this problem through extensive research into the coherence of the relationship between the employee and the company, and the factors that influence this relationship. Aligning the relationship between an individual and the organization (PO fit) increases the probability of an individual's entering and remaining with the organization. The perception of this compliance is the predictor of the decision to join the organization, directs the behavior of individuals while working in the organization and influences the decision to leave the organization (Greguras \& Diefendorff, 2009, 467). Organizations employ different individuals and, therefore, need to harmonize their PO fit with a specific category of employees, in which way they can improve organizational outcomes (Sekiguchi, 2007, 122).

In the given context, recruitment and selection activities offer a possibility of aligning PO fits, which can affect organizational outcomes, such as performance or employee satisfaction. Generally, the subject of the research carried out in this paper is the impact of employee recruitment activities on employee satisfaction through the development of the employer brand. 
The purpose of this article is to determine, through an analysis of the recruitment activities containing the pre-selection criteria, its impact on the satisfaction of the existing employees as an important intangible factor for attracting new employees. In addition to recruitment, the employer brand, as an individual's perception of the company or the alignment of $\mathrm{PO}$ fits, is another intangible factor that can enhance the attractiveness of the organization and, therefore, is the subject matter of the research study presented in this paper.

The aim of the research study is to determine whether the recruitment process has an impact on the satisfaction of employees and whether the employer brand can strengthen this relationship and increase employee satisfaction.

Based on the results of the theoretical research, a research model based on three hypotheses was designed, which was done through the statistical data processing obtained from the original research. The data were collected by applying the survey method in the form of a structured questionnaire. The results of the regression analysis used to test the hypotheses have shown the existence of a statistically significant influence between the observed variables. The results obtained through this research have practical implications through determining the factors that can positively affect the solving of the problem of the deficit of candidates for a certain position in the organization.

The work is structured into seven parts. After the introductory part, the second part gives an overview of the relevant literature used as the basis for defining the research model and for the formulation of the hypotheses. In the third part, the research methodology is presented, and in this part the primary data collection method, the sample statistics and the presentation of the statistical techniques applied in testing the hypotheses are presented. The fourth part accounts for the results of the research study through the presentation of the results of the regression analysis carried out when testing the hypotheses. Also, this part of the paper discloses the results of the reliability analysis and the descriptive statistical analysis. In the fifth part of the paper, the discussion of the results obtained is presented, and the practical implications of the conducted research study as well. At the end of the paper, the conclusions are given, prior to which the limitations of the research done and the direction for future research are accounted for in a separate part.

\section{LITERATURE REVIEW}

There are two possibilities for organizations to fulfill their needs for human resources, i.e. knowledge, skills and talents:

- internal recruitment, through their own talent development, and

- external recruitment, through the acquisition of talents from the environment or other organizations.

External employee recruitment is one of the initial human resource management's activities that define the preliminary criteria for individuals' entering the organization. Recruitment can be understood as a set of the activities whose primary goal is to identify, attract and engage the best individuals who will enable the achievement of the strategic goals of the company (Ofori \& Aryeetey, 2011, 48).

In academic research and HRM practice, it is often the primary task to provide a realistic piece of information about the job in order for candidates to know what is expected of them, with the primacy of applying traditional recruitment methods. In the current business environment, only vacancy advertising is often not sufficient to ensure the required number of quality candidates. Competition in the labor market requires that the company should implement the recruitment process in a timely manner, using modern technological solutions, whereby recruitment itself must be guided by a marketing strategy (Slavić, Bjekić and Berber, 2017, 89). In general, candidate recruitment can be internal and external, with companies applying different approaches in practice and using different means of advertising for vacant 
posts. In addition to traditional ways, it is especially attractive and useful to recruit through the Internet and social networks. Internet sites and social networks often provide candidates with a variety of information regarding the work, working conditions, organizational culture, necessary qualifications, the exchange of knowledge, experience, and so on.

The recruitment process can have a positive impact on different organizational outcomes. A quality-driven selection process has a positive impact on an increase in the retention rate, organizational commitment and the productivity of employees (Sutanto \& Kurniawan, 2016, 377). In order to achieve the appropriate level of employee satisfaction, the recruitment process needs to be implemented so that employees know what is expected of them at the workplace. It is known that the "blind advertising" strategy in which the company seeks to hide the key information is not efficient as employees are not familiar with what is expected of them, and do not accept the job or quickly leave it. When the employee in the recruitment process is provided with all of the relevant pieces of information regarding what is expected of him, as well as of what he can expect from the company, there is no inflationary expectation at the workplace, but it is easier to meet work demands, reduce the rate of absenteeism, increase employees' confidence in the company, as well as the level of their job satisfaction (Suszko \& Breaugh, 1986, 521). As a result of satisfied employees, there are improvements in performance, efficiency, improvements in interpersonal relationships, reductions in the fluctuation and absenteeism rates (Inuwa, 2015, 289). Summarizing the above said, and in the context of the research involved in this work, it is possible to formulate the first hypothesis:

H1: Employee recruitment has a statistically significant, positive impact on employee satisfaction.

The overall recruitment activity can usually be divided into three phases: generating applicants, retaining applicants, and influencing decisions on accepting a job. Therefore, it is necessary to properly manage the recruitment process since any activity in the process can affect the number of applicants, their decision to apply and accept the job if offered (Breaugh \& Starke, 2000, 407). The sources used to advertise the workplace, as well as the image of the company, play a very important role. In order for the recruitment process to be successful, i.e. to attract and retain the best candidates from the labor market, marketing principles must be adhered to, especially so the principles of branding. The employer brand is also one of the ways in which a company differentiates itself from others and presents itself as a unique and desirable place to work. Developed as a result of the integration of marketing and human resources management, the employer brand represents a company's effort to communicate the organizational culture, systems, values and interpersonal relationships that make a workplace different from others (Singh \& Rokade, 2014, 45).

The implementation of the marketing and branding principles in the human resource management discipline leads to the emergence of the employer brand that can be used as a means of attracting and retaining the best candidates from the labor market. Since the emergence of this concept in 1996, many researchers have sought to identify the key characteristics and factors that a particular company identifies as a unique and desirable place to work.

The conceptual designers of this concept, T. Ambler and S. Barrow $(1996,187)$, define the employer brand as a set of the functional, economic and psychological benefits that are secured by employment, and which are characteristic of the employer's enterprise. It is a process of building a picture in the minds of labormarket candidates that the company is the "preferred place to work in" (Ewing, Pitt, Bussy \& Berthon, 2002, 12). As the process of building a recognizable and unique identity, the employer brand is the concept of the enterprise that makes it different from others (Backhaus \& Tikoo, 2004, 502). So, the company will be an attractive or good place to work in if it offers a good balance between life and work, stimulating compensations, quality products and services, a challenging task, promotion, participation in humanitarian activities (Tanwar \& Prasad, 2016, 4-5). In this way, the employer brand becomes a strategic 
tool for attracting and retaining talents from the labor market (Mihalce, 2017, 290).

In order to build the employer brand, it is necessary to follow the marketing principles. First, it is necessary to perform an internal analysis, i.e. to examine the existing system of values, culture, employees, human resources management policy and the competitive position, and on the basis of such analyses to determine which benefits can be offered to the existing and potential employees. In the next step, external marketing efforts are identified and attracted by the candidates who match their capabilities and their value system to the company's. Internal marketing is the last stage in building an employer brand. In internal marketing activities, the company delivers the promised value to its employees in order to create the motivated workforce loyal to the company (Backhaus \& Tikoo, 2004, 502-503; Chhabra \& Sharma, 2014, 51).

As a result of building the employer brand, two very important outcomes emerge: brand associations and loyalty to the brand (Backhaus \& Tikoo, 2004, 504). Employer brand associations are the ideas that emerge in employees' awareness when thinking of a particular company and of the reasons for which it is good to work in it. In other words, employer brand associations shape the image of an enterprise as an employer in the labor market. Loyalty to the employer brand represents employees' commitment to the company. If the company has a developed employer brand, the employees will not easily change their jobs, even if there is another possibility of employment (Chhabra \& Sharma, 2014, 50-51).

As a result of the creation of the employer brand, the company approaches qualified employees, improves interpersonal relationships, increases performance and retention rates, the identification with the organization and a commitment to the company and employees' self-confidence easily and at lower costs (Chhabra \& Sharma, 2014, 51). Like the recruitment process, the employer brand also has an impact on job satisfaction. The results of numerous studies have shown that the employer brand positively links to the level of employee satisfaction with the work
(Schlager, Bodderas, Maas \& Cachelin, 2011, 502; Yalim \& Mizrak, 2017, 99; Davies, Mete \& Whelan, $2018,74)$. The results obtained can also be explained by the fact that business satisfaction factors, such as good interpersonal relationships, challenging work, stimulating compensations and the like, are already included in the employer brand and provided to employees. The above research is the basis for formulating the second hypothesis in this paper, which reads as follows

H2: The employer brand has a statistically significant positive impact on employee satisfaction.

As the employer brand represents an effective means of attracting labor market candidates, its significance in the human resource management process (Starineca, $2015,27)$ is evident, primarily in the recruitment process. Those enterprises that have a developed employer brand are distinguished as recognizable and desirable places to work in, and have a positively built image in the public, thus acting positively on the perception of candidates (Gilani \& Cunningham, 2017, 242). There are two essential elements of this image: the employee's attitude towards the brand and the perceived characteristics, i.e. the benefits that the company offers to its employees, on the basis of which the decision to accept the job is made. By applying various techniques to attract candidates, a company can act on these elements and form a positive image in the public before the recruitment process has begun. This can be achieved through sponsorship activities, cooperation with schools, faculties and government agencies, participation in humanitarian activities, etc. (Agrawal \& Swaroop, 2011, 162). In this way, the recruitment process improves, the best candidates are attracted, and simultaneously the company's resources are saved (Khalid \& Tariq, 2015, 358).

The employer brand can be used as a strategic tool in the recruitment process that will enable the attracting and retaining of talents from the labor market (Franca \& Pahor, 2012, 90). If a company has built a good reputation in the public, the recruitment process is facilitated as the candidate already has a positive attitude towards the given company (Saini, Gopal \& Kumari, 2015, 38). In some cases, as a result of such 
a reputation, an enterprise is able to attract those candidates who are willing to work in the given company, as their value system fits into the value system of that company. This can be explained by the theory of social identity, according to which people tend to be members of a particular group because they have common characteristics, values and attitudes (Khalid \& Tariq, 2015, 356).

A number of studies have shown that the companies that have developed the employer brand more easily implement the recruitment process, attract and retain more qualified candidates, and achieve numerous other benefits (Lemmink, Schuijf \& Streukens, 2003; 11, Collins \& Stevens, 2002). As a result of the implementation of the employer brand strategy in the recruitment process, employees have a higher level of trust and feel a higher degree of identification with and commitment to the company, which increases their work ethics. Numerous benefits are also present for employers. A positive public image allows them access to the best candidates, new recruitment strategies are developed, the retention rate increases, as well as employee satisfaction does (Tanwar \& Prasad, 2016, 861). Satisfied employees transfer their experience to others, in which manner positive wordof-mouth propaganda additionally strengthens the reputation of the company on the market. Respecting these benefits, the third hypothesis of this study is formulated, reading as follows:

H3: The employer brand is the mediator of the positive relationship between employee recruitment and employee satisfaction.

\section{RESEARCH METHODOLOGY}

An empirical research study was conducted so as to identify the impact of employee recruitment and the employer brand on employee satisfaction. In order to collect the primary data, the survey method was used in the form of a questionnaire consisting of 25 statements, of which 5 items refer to employee recruitment, with the 10 statements measured by the employer brand, whereas the independent variable, employee satisfaction, is measured by 10 statements. The survey was conducted through a direct contact with the respondents, leaving them the time to complete the questionnaire. The first part of the questionnaire contains the questions intended for collecting descriptive data about the respondents and the business organizations included in the sample. The second part of the questionnaire contains the observations that observe the condition of the observed variables. The findings were based on the relevant previous research done in this field, which created the assumption of the high consistency of the conducted research ( $\mathrm{Lu}$, While \& Barriball, 2007; Schlager, Bodderas, Maas \& Cachelin, 2011; Peltokorpi \& Jintae Froese, 2016). The respondents showed a degree of agreement with the stated conclusions on the five-point Likert scale.

Using the data of the Business Registers Agency, the business organizations were randomly selected and a procedure for collecting data was initiated. The survey covered 180 companies, whose managers and employees assessed the employee recruitment process, the strength of the employer brand and satisfaction. The largest number of the companies in the given sample employ in excess of 250 employees, being followed by the companies with between 50 and 250 employees. The development of the employer brand in the companies with less than 10 employees is impossible in practical terms. Nevertheless, these companies were not excluded from the sample for the two reasons: firstly, these companies also take care of their reputation in the public, and secondly, their number in the sample is small enough so as not to affect the results of the research. In the sample, almost 50 percent of the respondents from the multinational companies or the other smaller companies operating in the Republic of Serbia, whose owners are from abroad, are also present. Their presence in the sample enables a better understanding of the employment context in the Republic of Serbia because these companies employ a significant number of employees. The other data related to the sample statistics for the companies and the respondents are given in Table 1.

The processing of the collected data was carried out with the computer support of the IBM SPSS Statistics 
statistical package, Version 23 (Statistical Package for Social Sciences). The application of the regression analysis measured the influence of the independent variable on the dependent and the mediator effect was tested through the results obtained by the multiple regression analysis. In order to determine the statistical significance of the obtained results, the following confidence levels were used: $\alpha=0.05, \alpha=$ 0.01 .

Table 1 The sample structure: the summary

\begin{tabular}{l|cc}
\hline Variable & $\begin{array}{c}\text { Absolute } \\
\text { frequency }\end{array}$ & $\begin{array}{c}\text { Proportion } \\
(\%)\end{array}$ \\
\hline Number of employees & 1 & $0.6 \%$ \\
2-9 employees & 35 & $19.4 \%$ \\
10-49 employees & 64 & $35.6 \%$ \\
50-249 employees & 80 & $44.4 \%$ \\
Over 250 employees & & \\
Business & 126 & $70.0 \%$ \\
Production & 28 & $15.6 \%$ \\
Trade & 26 & $14.4 \%$ \\
Service & & \\
Ownership & 90 & $50.0 \%$ \\
Domestic private capital & 88 & $48.9 \%$ \\
Foreign private capital & 2 & $1.1 \%$ \\
State & & \\
Sex of respondents & 81 & $45.0 \%$ \\
Male & 99 & $55.0 \%$ \\
Female & & \\
Education & 62 & $34.4 \%$ \\
Secondary education & 32 & $17.8 \%$ \\
Higher education & 86 & $47.8 \%$ \\
High education & & \\
\hline
\end{tabular}

Source: Authors

\section{RESEARCH RESULTS}

In order to determine the internal consistency of the items used, Cronbach's alpha coefficient was calculated. The values obtained for the employee recruitment variables, the employer brand and employee satisfaction are 0.908, 0.884, 0.910, respectively, and the presented values are indicative of a high level of the internal consistency of the given findings. In addition, Table 2 shows an overview of the results of the descriptive statistical analysis (the arithmetic mean and the standard deviation). Based on the given values, it is concluded that the highest degree of agreement between the respondents is achieved in the case of the developed employer brand, since the highest values of the arithmetic mean are identified in the conclusions related to the quality of the products/services of the given company, as well as its potential for future development.

In order to test the defined hypotheses, a regression analysis was performed by using the smallest squares method. In addition, in order to determine the mediator effect, a procedure developed by R. M. Baron and D. A. Kenny (1986) was implemented. The above procedure is based on the creation of several regression models, which relate to:

- determining the impact of the independent variable on the variable representing the mediator;

- determining the impact of the independent variable on the analyzed dependent variable;

- determining the influence of the mediator on the dependent variable.

The last step is the implementation of a multiple regression analysis, which implies the identification of the influence of the independent variable and the mediator on the dependent variable. According to R. M. Baron and D. A. Kenny (1986, 1177), the mediating influence exists when, in the last step, there is a decrease in the influence of the independent variable on the dependent variable, or the effect of the independent variable on the dependent variable becomes insignificant.

In accordance with the procedure described, four regression models were created. The regression model 1 examines the nature and strength of the relationship between the employee recruitment activities and the created employer brand, with the dependent 
Table 2 The reliability analysis and the descriptive statistical analysis

\begin{tabular}{|c|c|c|c|}
\hline \multicolumn{4}{|c|}{ Recruitment: Cronbach's alpha coefficient 0.908} \\
\hline & Item & Mean & St. dev. \\
\hline RZ1 & $\begin{array}{l}\text { The company spends considerable resources on finding suitable individuals for } \\
\text { vacancies. }\end{array}$ & 3.02 & 1.286 \\
\hline $\mathrm{RZ2}$ & Finding suitable individuals for vacancies is an objective and impartial process. & 3.49 & 1.197 \\
\hline $\mathrm{RZ3}$ & $\begin{array}{l}\text { Various sources, such as the Internet, specialized agencies or human resources experts, } \\
\text { are used to find potential candidates. }\end{array}$ & 3.57 & 1.260 \\
\hline RZ4 & The company uses different strategies to attract talented individuals. & 3.30 & 1.246 \\
\hline RZ5 & The company is trying to engage people who have the ability to think creatively. & 3.39 & 1.378 \\
\hline \multicolumn{4}{|c|}{ Employer brand: Cronbach's alpha coefficient 0.884} \\
\hline & Item & Mean & St. dev. \\
\hline BP1 & As the employer, the firm in which I work stands out in relation to other firms. & 4.02 & 1.020 \\
\hline BP2 & To me, the firm in which I work is attractive as an employer. & 3.99 & 1.069 \\
\hline $\mathrm{BP}_{3}$ & Other people think the company where I work is a good place to work in. & 4.12 & 1.029 \\
\hline $\mathrm{BP}_{4}$ & Jobs in the company are paid above the average. & 3.06 & 1.291 \\
\hline $\mathrm{BP}_{5}$ & Work is done in good working conditions. & 3.79 & 1.075 \\
\hline BP6 & There is a good balance between the time spent at work and free time. & 3.50 & 1.275 \\
\hline BP7 & There are good opportunities for promotion and an improvement in the company. & 3.53 & 1.243 \\
\hline BP8 & Relationships among the employees are good. & 3.90 & 1.088 \\
\hline BP9 & The company offers quality products and/or services. & 4.36 & .881 \\
\hline BP10 & The company has a good potential for development in the forthcoming period. & 4.20 & 1.000 \\
\hline \multicolumn{4}{|c|}{ Employee satisfaction: Cronbach's alpha coefficient 0.910} \\
\hline & Item & Mean & St. dev. \\
\hline ZZ1 & Generally, I am satisfied with the fact that I work in this company. & 3.88 & 1.035 \\
\hline $\mathrm{ZZ2}$ & I am satisfied with the working environment which I do my job in. & 3.94 & .966 \\
\hline ZZ3 & I enjoy my work. & 3.75 & 1.141 \\
\hline ZZ4 & I am adequately paid for the job I do. & 3.18 & 1.283 \\
\hline ZZ5 & Doing my current job is not too stressful. & 2.97 & 1.256 \\
\hline ZZ6 & The job gives me a sense of personal fulfillment. & 3.49 & 1.289 \\
\hline ZZ7 & In the company, I have all the necessary conditions and resources for doing business. & 3.84 & 1.091 \\
\hline ZZ8 & I am satisfied with collegiality at work. & 3.97 & .968 \\
\hline ZZ9 & I am satisfied with the relationship with my superiors (managers, bosses, directors). & 3.94 & 1.051 \\
\hline ZZ10 & I have a feeling that the company takes care of its employees. & 3.60 & 1.198 \\
\hline
\end{tabular}

Source: Authors

variable being determined independent in $50.9 \%$ of the cases $\left(R^{2}=0.509\right)$. Within the regression model 2 , the interdependence of recruitment and employee satisfaction activities was observed, whereby the resulting value of $\mathrm{R}^{2}$ points to a somewhat worse model than the previous one $\left(R^{2}=0.460\right)$. The value of the beta coefficient is relevant at the level of 0.01 , whereby the positive value of this coefficient imposes the conclusion that there is a positive influence of recruiting employees on their satisfaction.
The third regression model is aimed at establishing a link between the employer brand and employee satisfaction. The employer brand, as the independent variable, determines the dependent variable change, employee satisfaction in $57.7 \%$ of the cases $\left(\mathrm{R}^{2}=\right.$ 0.577). Based on the results shown and the positive value of the beta coefficient, which is significant at the 0.01 level, a statistically significant positive effect of the created employer brand on job satisfaction is determined. 
The fourth model presented in Table 3 implies the implementation of the multiple regression analysis, which is aimed at identifying the impact of employee recruitment and the employer brand on the dependent variable, employee satisfaction. In this case, even $61.5 \%$ of the variability of the dependent variable is explained by the independent variables involved. Multicollinearity is not a problem, given the fact that the variance factor varies by less than 5 . There is no problem with autocorrelation, as the Durbin-Watson coefficient approaches 2 .

Table 3 The results of the regression analysis

\begin{tabular}{|c|c|c|c|c|}
\hline Variable & $\begin{array}{l}\text { Model } \\
\text { 1: the } \\
\text { employer } \\
\text { brand } \\
\text { dependent } \\
\text { variable }\end{array}$ & $\begin{array}{l}\text { Model } \\
\text { 2: the } \\
\text { employee } \\
\text { satisfaction } \\
\text { dependent } \\
\text { variable }\end{array}$ & $\begin{array}{l}\text { Model } \\
\text { 3: the } \\
\text { employee } \\
\text { satisfaction } \\
\text { dependent } \\
\text { variable }\end{array}$ & $\begin{array}{l}\text { Model } \\
4: \text { the } \\
\text { employee } \\
\text { satisfaction } \\
\text { dependent } \\
\text { variable }\end{array}$ \\
\hline Recruitment & $0.714^{* *}$ & $0.678 * *$ & & $0.277^{* *}$ \\
\hline $\begin{array}{l}\text { Employer } \\
\text { brand }\end{array}$ & & & $0.760 * *$ & $0.562 * *$ \\
\hline $\mathrm{R}^{2}$ & 0.509 & 0.460 & 0.577 & 0.615 \\
\hline Adjusted $\mathrm{R}^{2}$ & 0.506 & 0.457 & 0.575 & 0.610 \\
\hline ANOVA F & $181.567^{* *}$ & $149.032 * *$ & $238.861 * *$ & $138,900 * *$ \\
\hline
\end{tabular}

Agenda: ${ }^{* *} p<0.01 ;{ }^{*} p<0.05$. The table shows the beta coefficient.

Source: Authors

\section{DISCUSSION AND PRACTICAL IMPLICATIONS}

There are three hypotheses set in this paper. The first hypothesis seeks to point out the importance of recruiting employees in order to generate a higher degree of satisfaction. The results of the conducted statistical analyses have shown that the way of recruiting employees is positively reflected in the level of employee satisfaction, which is confirmed in the works of M. K. Suszko and J. A. Breaugh (1986), and J. A. Breaugh (2008). Therefore, the H1 hypothesis has been fully confirmed.

The second hypothesis has been defined in order to identify the interdependence of the developed employer brand and employee satisfaction. In the concrete case, the image of the company built in the eyes of its employees, i.e. the brand, has a significant positive impact on employee satisfaction, as is confirmed in T. Schlager et al (2011), G. Davies, M. Mete and S. Whelan (2017), and F. Yalim and K. C. Mizrak (2017), due to which fact the $\mathrm{H} 2$ hypothesis is fully accepted.

The third hypothesis has been set so as to determine the median impact of the developed employer brand in the case of the interdependence between the recruitment process and the level of employee satisfaction. The procedure implemented in the form of the created regression models shows that in the last step, i.e. in the regression model, there is a reduction in the strength of the recruitment impact on employee satisfaction. Therefore, the strong employer brand is the mediator of the influence between employee recruitment and their satisfaction, which is the reason why the $\mathrm{H} 3$ hypothesis has also been confirmed.

The results of the conducted research study have important practical implications:

- The obtained results are a confirmation that the desired level of employee satisfaction can be influenced through the recruitment process, which should lead to the achievement of a superior performance through the motivation mechanisms.

- The way human resources management activities are conducted has an important impact on the creation of an image of the given employer in the eyes of the public, namely his potential and existing employees. Therefore, it is necessary that systematic efforts towards the development of a positive, unique and recognizable employer brand should be invested, taking into account the loyalty of the existing employees to the employer and their commitment to the realization of the set tasks. 
- The built employer brand also affects employee satisfaction, so it should be seen as an important precondition for the effective recruitment process. By investing in the development of the employer brand, employee satisfaction can increase, the attractiveness for appropriate candidates simultaneously being enhanced.

- Employee satisfaction is a prerequisite for productivity growth, the improvement of interpersonal relationships, as well as a reduction in the fluctuation and absenteeism rates (Inuwa, 2015, 289).

It is, therefore, important to have an integral approach in generating the desired level of employee satisfaction, starting with: attracting potential candidates; selecting and retaining the best candidate; creating a favorable environment for work, with a focus on achieving a balance between job requirements and private life, which in turn contributes to a reduction in the absenteeism and fluctuation rates.

\section{LIMITATIONS AND FUTURE RESEARCH}

Despite the contribution of the research conducted for the purposes of producing this paper, it has a number of limitations, which is also a guide for future research. The first is the structure of the sample, which is considered to be a potential constraint from the aspect of the core business. Since the sample constitutes enterprises operating within the manufacturing, trade and services sectors, each of the sectors listed has certain specificities that primarily relate to the performance of certain operations that may affect the observed variables in the survey. Consequently, the research focus needs to be carried out so that the sample includes companies from one particular sector. In this way, the generalization of attitudes will be avoided, and the results obtained would contribute to the improvement of the human resources management practices within the given activity or sector, as well as to providing guidelines for the development of a positive employer brand, simultaneously respecting the specific nature of the specific activity.
The second potential restriction is that concerning the size of the sample. Compared to the studies previously conducted in this area, the need for an increase in the number of interviewed respondents is imposed. This constraint is due to a relatively underdeveloped business culture and the closeness of enterprises in transition economies, which inevitably reflects a limited number of options for collecting questionnaires and increasing the number of units in a sample.

The third limitation refers to the examination of employees' attitudes about the method of recruiting. Namely, the respondents did not agree on the key source of recruitment, since the two key sources, i.e. internal and external recruitment, are referred to in the literature. In the future, it is therefore necessary to distinguish between the two types of recruitment, focusing on the identification of the effectiveness of the given type, especially in order to generate a higher degree of employee satisfaction.

The fourth limitation concerns the absence of variables or statements to evaluate the recruitment process or the effects of the recruitment strategy applied. On the other hand, in practice and in the professional literature, the view that the purpose of recruitment is not about attracting the best candidates, but rather the candidates who are best suited to the organization and those candidates who are best fitted with the organization (the best fit model), is increasingly prevalent. Thus, the importance of traditional criteria for successful recruitment activities is simultaneously relativized.

In addition to the foregoing, future research should focus on incorporating the contemporary dimensions of the employer brand. In this way, we would gain an insight into the overall potential of the employer brand as a strategic tool in carrying out recruitment activities and provide recommendations for formulating the principle of building a positive image of the company in the eyes of the existing and potential employees. Ultimately, in terms of determining the level of employee satisfaction, it is recommended that the Minnesota Satisfaction Questionnaire (Martins \& Proenca, 2012, 4) should be used and that the Job 
Descriptive Index (Tanwar \& Prasad, 2016, 880) should be calculated as well. The instruments created would enable the empirical results presented in the paper, as well as a detailed analysis of the various aspects of job satisfaction.

\section{CONCLUSION}

The results of the regression analysis demonstrate that employee recruitment has a statistically significant impact on employee satisfaction, as well as the employer brand, thus confirming the $\mathrm{H} 1$ and $\mathrm{H} 2$ hypotheses. Also, through the model of the multiple regression analysis, the mediating role of the employer brand has been confirmed in the paper, thus confirming the $\mathrm{H} 3$ hypothesis. In practical terms, the results of the research presented in the paper show that, through directing the employee recruitment process, important organizational outcomes can be influenced, such as, for example, employee satisfaction. In addition, representing a company in the public as a desirable employer through the development of the employer brand also contributes to an increase in employee satisfaction. The general conclusion is that the mentioned "recruitment" and "employer brand" variables can positively influence employee satisfaction, which is an important prerequisite for creating an image of the company as an attractive place to work in. This increases the likelihood of attracting new talents to the organization and potentially solves the problem of the current deficit in talents and skills in the local and global labor markets. By investing in certain dimensions of the employer brand, a company actually works on aligning PO fits as an important assumption of attracting and retaining individuals within the company.

Defining the recruitment process implementation method can affect employee behavior in the organization and their satisfaction with the work they do, which has been confirmed in the paper. The mediator influence of the employer brand, which in practical terms has been determined by this research study, accounts for the fact that investing in the employer brand increases the degree of individuals' consent to the pre-selection criteria contained in employee recruitment and also increases the degree of the identification of individuals with the company. On the other hand, the inflow of potential candidates into recruitment activities can be significantly reduced through the selection process, which is the reason why it is necessary to include the selection process in future research, although in a situation where there is a significant shortage of human resources in the labor market, selection criteria are modified and adjusted to current circumstances.

\section{REFERENCES}

Agrawal, R. K., \& Swaroop, P. (2011). Buliding employer brand image through early recruitment practices: a study in Indian context. Asia - Pacific Business Review, 7(2), 160-169. doi:10.1177/097324701100700215

Ambler, T., \& Barrow, S. (1996). The employer brand. The Journal of Brand Management, 4(3), 185-206. doi:10.1057/ bm.1996.42

Backhaus, K., \& Tikoo, S. (2004). Conceptualizing and researching employer branding. Career Development International, 9(5), 501-517. doi:10.1108/13620430410550754

Baron, R. M., \& Kenny, D. A. (1986). The moderator-mediator variable distinction in social psychological research: Conceptual, strategic, and statistical considerations. Journal of personality and social psychology, 51(6), 1173-1182. doi. org/10.1037/0022-3514.51.6.1173

Boston Consulting Group. (2018). Decoding Global Talent. Boston, US: Retrieved June 25, 2018, from https://www.bcg. com/publications/2018/decoding-global-talent.aspx

Breaugh, J. A. (2008). Employee recruitment: Current knowledge and important areas for future research. Human Resource Management Review, 18(3), 103-118. doi:10.1016/j. hrmr.2008.07.003

Breaugh, J. A., \& Starke, M. (2000). Research on employee recruitment: So many studies so many remaining questions. Journal of Management, 26(3), 405-434. doi:10.1177/014920630002600303

Chhabra, L. N., \& Sharma, S. (2014). Employer branding: Strategy for improving employer attractiveness. International Journal of Organisational Analysis, 22(1), 48-60. doi:10.1108/IJOA-09-2011-0513 
Collins, C. J., \& Stevens, C. K. (2002). The relationship between early recruitment - related activities and the application decision of new labor - market entrants: A brand equity approach to recruitment. Journal of Applied Psychology, 87(6), 1121-1133.

Davies, G., Mete, M., \& Whelan, S. (2018). When employer brand image aids employee satisfaction and engagement. Journal of Organizational Effectiveness: People and Performance, 5(1), 64-80. doi:10.1108/JOEPP-03-2017-0028

De Smet, A., \& Gagnon, C. (2018). Organizing for the age of urgency. McKinsey Quarterly, January 2018. Retrieved June 25, 2018, from https://www.mckinsey.com/businessfunctions/organization/our-insights/organizing-for-theage-of-urgency

Ewing, M. T., Pitt, L. F., Bussy, N. M., \& Berthon, P. (2002). Employment branding in the knowledge economy. International Journal of Advertising, 21(1), 3-22. doi:10.1080/0 2650487.2002.11104914

Franca, V., \& Pahor, M. (2012). The strength of the employer brand: Influences and implications for recruiting. Journal of Marketing \& Management, 3(1), 78-122.

Gilani, H., \& Cunningham, L. (2017). Employer branding and its influence on employee retention: a literature review. The Marketing Review, 17(2), 239-256. doi:10.1362/14693471 7X14909733966209

Greguras, G. J., \& Diefendorff, J. M. (2009). Different fits satisfy different needs: Linking person-environment fit to employee commitment and performance using selfdetermination theory. Journal of Applied Psychology, 94(2), 465-477. doi:10.1037/a0014068

Inuwa, M. (2015). The impact of job satisfaction, job attitude and equity on employee performance. The International Journal of Business and Management, 3(5), 288-293.

Khalid, S., \& Tariq, S. (2015). Impact of employer brand on selection and recruitment process. Pakistan Economic and Social Review, 53(2), 351-372.

Lanvin, B., \& Evans, P. (2017). The Global Talent Competitiveness Index. Fontainebleau, France: INSEAD Business School, Adecco Group and Human Capital Leadership Institute.

Lu, H., While, A. E., \& Barriball, K. L. (2007). Job satisfaction and its related factors: A questionnaire survey of hospital nurses in Mainland China. International Journal of Nursing Studies, 44(4), 574-588. doi:10.1016/j.ijnurstu.2006.07.007
ManpowerGroup. (2018). Talent Shortage Survey: Solving the Talent Shortage: Build, Buy, Borrow and Bridge. Employment Outlook Survey. Milwaukee, US: Retrieved June 25, 2018, from https://go.manpowergroup.com/talent-shortage-2018

Martins, H., \& Proença, T. (2012). Minnesota Satisfaction Questionnaire-Psychometric properties and validation in a population of Portuguese hospital workers. FEP JournalEconomics \& Management: Working Paper, 471(1), 1-23.

Ofori, D., \& Aryeetey, M. (2011). Recruitment and selection practices in small and medium enterprises: Perspectives from Ghana. International Journal of Business Administration, 2(3), 45-60. doi:10.5430/ijba.v2n3p45

Peltokorpi, V., \& Jintae Froese, F. (2016). Recruitment source practices in foreign and local firms: A comparative study in Japan. Asia Pacific Journal of Human Resources, 54(4), 421-444. doi:10.1111/1744-7941.12076

Saini, G. K., Gopal, A., \& Kumari, N. (2015). Employer brand and job application decisions: Insights from the best employers. Management and Labor Studies, 40(1-2), 34-51. doi:10.1177/0258042X15601532

Schlager, T., Bodderas, M., Maas, P., \& Cachelin, J. L. (2011). The influence of the employer brand on employee attitudes relevant for service branding: An empirical investigation. Journal of Services Marketing 25(7), 497-508. doi:10.1108/08876041111173624

Sekiguchi, T. (2007). A contingency perspective of the importance of PJ fit and PO fit in employee selection. Journal of Managerial Psychology, 22(2), 118-131. doi:10.1108/02683940710726384

Singh, M., \& Rokade, V. (2014). Employer branding: A strategic dimension for employee retention. Journal of Marketing and Consumer Research, 5, 44-49.

Slavić, A., Bjekić, R. i Berber, N. (2017). Uloga interneta i društvenih mreža u procesu regrutacije i selekcije. U A. Grubor (Ur.). Strategijski menadžment $i$ sistemi podrške odlučivanju u strategijskom menadžmentu - SM2017 (str. 88-96). Subotica, Republika Srbija: Ekonomski fakultet u Subotici Univerziteta u Novom Sadu.

Starineca, O. (2015). Employer brand role in HR recruitment and selection. Economics and Business, 27(1), 58-63. doi:10.1515/eb-2015-0009 
Suszko, M. K., \& Breaugh, J. A. (1986). The effects of realist job previews on applicant self-selection and employee turnover, satisfaction, and coping ability. Journal of Management, 12(4), 512-523. doi:10.1177/014920638601200406

Sutanto, E. M., \& Kurniawan, M. (2016). The impact of recruitment, employee retention and labor relations to employee performance on batik industry in Solo city, Indonesia. International Journal of Business and Society, 17(2), 375-390.

Tanwar, K., \& Prasad, A. (2016). The effect of employer brand dimensions on job satisfaction: Gender as a moderator. Management Decision, 54(4), 854-886. doi: 10.1108/MD-082015-0343
Yalim, F., \& Mizrak, K. C. (2017). A field study on the relationship between employer brand and employee satisfaction. International Review of Management and Marketing, 7(2), 92-103. Tanwar, K., \& Prasad, A. (2016). The effect of employer brand dimensions on job satisfaction: gender as a moderator. Management Decision, 54(4), 854-886. doi: 10.1108/MD-08-2015-0343

Yalim, F., \& Mizrak, K.C. (2017). A field study on the relationship between employer brand and employee satisfaction. International Review of Management and Marketing, 7(2), 92-103.

$$
\begin{array}{r}
\text { Received on } 9^{\text {th }} \text { July } 2018, \\
\text { after revision, } \\
\text { accepted for publication on } 22^{\text {nd }} \text { August } 2018 \\
\text { Published online on } 27^{\text {th }} \text { August } 2018
\end{array}
$$

Marko Slavkovic is an assistant professor at the Faculty of Economics, University of Kragujevac. He received his Ph.D. at the Faculty of Economics in Kragujevac, in the field of Strategic human resource management. He teaches on the graduate, master and doctoral academic studies. The key areas of his scientific research interests are Management and Strategic human resource management.

Goran Pavlovic is a PhD student at the Faculty of Economics, University of Kragujevac. The areas of his research interests are Human resources management, Organizational behavior and Competitive advantage.

Marijana Simic is a researcher at the Faculty of Economics, University of Kragujevac, where she is engaged on the subjects in the field of Business Economics. She is a PhD student at the Faculty of Economics, University of Kragujevac. The areas of her research interest are Human resources management, Entrepreneurship and Organizational behavior. 


\title{
POVEZANOST REGRUTOVANJA I SATISFAKCIJE ZAPOSLENIH: VERIFIKACIJA MEDIJATORSKE ULOGE BRENDA POSLODAVCA
}

\author{
Marko Slavković'*, Goran Pavlović2 i Marijana Simić \\ 'Ekonomski fakultet Univerziteta u Kragujevcu \\ ${ }^{2}$ Student doktorskih studija Ekonomskog fakulteta Univerziteta u Kragujevcu
}

Transformacija kapitalno intenzivne u znanjem vođenu privredu označila je početak nove epohe $\mathrm{u}$ poslovanju preduzeća. Realizacija poslovnih aktivnosti u izuzetno dinamičnom okruženju, u mnogome, umanjila je značaj tradicionalnih koncepata i tehnika, zbog čega je fokus na ljudskim resursima i njihovom upravljanju. Shodno tome, preduzeće treba da privuče, zadrži i motiviše zaposlene, kako bi generisanjem visokog nivoa njihovog zadovoljstva osiguralo put ka realizaciji strategijskih ciljeva. Mogući pravac postizanja željene pozicije zasniva se na razvoju brenda poslodavca. Stoga, cilj ovog rada jeste da utvrdi kakav je uticaj prakse u realizaciji aktivnosti regrutovanja zaposlenih na njihovo zadovoljstvo, kao i uticaj brenda poslodavca, kao medijatora, na identifikovanu vezu između regrutovanja i zadovoljstva zaposlenih u Srbiji. Rezultati sprovedenog empirijskog istraživanja dokazuju postojanje statistički značajnog pozitivnog uticaja regrutovanja zaposlenih, kao i medijatorskog uticaja brenda poslodavca, na njihovo zadovoljstvo.

Ključne reči: regrutovanje, satisfakcija zaposlenih, brend poslodavca, talenti, model usklađenosti

JEL Classification: M12, M39, M51

\section{UVOD}

Digitalizacija poslovnog okruženja i razvoj pratećih tehnologija utiču na različite aspekte poslovanja i zahtevaju brza prilagođavanja novonastalim okolnostima, kako bi organizacije održale svoju konkurentsku prednost. Poznate konsultanske kuće

* Korespondencija: M. Slavković, Ekonomski fakultet Univerziteta u Kragujevcu, Đ. Pucara 3, 34000 Kragujevac, Republika Srbija; e-mail: mslavkovic@kg.ac.rs i HR agencije u svojim izveštajima ističu postojanje gepa u ponudi i tražnji veština i ljudskih resursa i ističu potrebu za strategijskim pristupom u rešavanju problema deficita talenata na globalnom nivou. U svom redovnom kvartalnom izveštaju, kompanija McKinsey navodi da digitalizacija zahteva urgentnu promenu postojećeg obrasca ponašanja organizacija $u$ domenu strukture, strategije i sposobnosti zaposlenih, naročito $\mathrm{u}$ domenu personalizacije programa za talente i postojećih modela liderstva (De Smet \& Gagnon, 2018, 44). ManpowerGroup $(2018,7)$ navodi 
da se trend nedostatka talenata na globalnom nivou nastavlja i da se u 2018. očekuje dvanaestogodišnji maksimum, a da su nedostatak prijavljenih kandidata i neiskustvo najčešći uzroci za nepopunjavanje pozicija, kao i da najveći problem sa deficitom talenata imaju kompanije sa preko 250 zaposlenih. Bostonska Konsultantska Grupa, u svom izveštaju o talentima, iznosi podatak da $57 \%$ učesnika u sporovedenom istraživanju želi da radi u inostranstvu, što je značajno manje $u$ odnosu na prethodno istraživanje, koje je sprovedeno u 2014. godini (Boston Consulting Group, 2018, 5). Prema Globalnom indeksu konkurentnosti talenata (Global Talent Competitiveness Index - GTCI), koji se formira na osnovu sposobnosti zemlje da privuče, razvije i zadrži talente, vodeće pozicije imaju razvijene zemlje sa visokim prihodima, pri čemu je utvrđen visok stepen korelacije između vrednosti GDP-a per capita i vrednosti GTCI (Lanvin \& Evans, 2017, 12). Pored evidentnog deficita talenata, navedeni izveštaji ukazuju na činjenicu da će visokorazvijene zemlje, koje trenutno pružaju najbolje uslove za privlačenje i zadržavanje talenata, imati manju ponudu talenata iz manje razvijenih zemalja zato što se smanjuju njihove aspiracije ka zapošljavanju van zemlje. Moguće uzroke ovakvom trendu treba tražiti u činjenici da sve veći broj manje razvijenih zemalja radi na sopstvenim programima zadržavanja talenata. Drugi zaključak koji proizilazi iz navedenih izveštaja ukazuje da velike kompanije, među kojima dominiraju multinacionalne kompanije, imaju mnogo više problema za popunjavanje pozicija nego male kompanije i mala i srednja preduzeća, što posredno može ukazivati na relativno manju privlačnost multinacionalnih kompanija kao poslodavca.

U nastojanju kompanija da zadovolje svoje potrebe za talentima na globalnom tržištu radne snage, područje delovanja HR menadžera i HR specijalista postaje konkurentski intenzivna. Simultani rad nacionalnih i kompanijskih lidera na privlačenju, razvoju i zadržavanju talenata ulazi u zonu opadajućih prinosa, što praktično znači da dodatni napor ne dovodi do povećanja broja kandidata koji se javljaju za otvorene pozicije. Zemlje sa visokim prihodima i kompanije sa dobrim kompenzacionim paketima smanjuju svoju atraktivnost kao mesta za rad i zapošljavanje zbog trenda smanjenja aspiracija talenata da posao traže $\mathrm{u}$ inostranstvu, pri čemu se odliv talenata iz manje razvijenih zemalja $u$ razvijene zemlje uzima kao ključni trend globalnih migracija. Suočeni, s jedne strane, sa činjenicom da ljudi, intelektualni kapital i talenti sve više postaju kritične tačke strategijskog uspeha organizacije, a da postojeći mehanizmi za privlačenje talenata ne daju očekivane rezultate, HR menadžeri i lideri kompanija su aktivni u identifikovanju drugih faktora koji mogu pozitivno uticati na privlačenje i zadržavanje talenata. Drugim rečima, blagostanje i visina kompenzacija, kao materijalni motivatori, postaju manje efektivni $\mathrm{u}$ privlačenju talenata, zbog čega se pažnja sve više usmerava na neopipljive faktore kao što su satisfakcija zaposlenih, brend poslodavca, intrizična motivacija ili balans između posla i slobodnog vremena.

Istraživači su doprineli rešavanju ovog problema, kroz ekstenzivno istraživanje usklađenosti odnosa između zaposlenog i kompanije i faktora koji utiču na ovaj odnos. Usklađivanjem odnosa pojedinca i organizacije (PO usklađenost), povećava se verovatnoća ulaska i ostanka pojedinca u organizaciji. Percepcija ove usklađenosti je prediktor odluke o priključivanju organizaciji, usmerava ponašanje pojedinaca dok rade $\mathrm{u}$ organizaciji i utiče na odluku o napuštanju organizacije (Greguras \& Diefendorff, 2009, 467). Organizacije zapošljavaju različite pojedince i zbog toga treba da usaglase svoju PO usklađenost sa konkretnom kategorijom zaposlenih, jer na taj način mogu da poboljšaju organizacione performanse (Sekiguchi, 2007, 122).

U datom kontekstu, aktivnosti regrutovanja i selekcije nude mogućnosti usaglašavanja PO usklađenosti, čime se može uticati na organizacione ishode, kao što su performanse ili zadovoljstvo zaposlenih. Predmet istraživanja ovog rada je uticaj aktivnosti regrutovanja zaposlenih na zadovoljstvo zaposlenih kroz razvoj brenda poslodavca.

Svrha rada je da se kroz analizu aktivnosti regrutovanja, koja sadrži predselekcione kriterijume, utvrdi njen uticaj na zadovoljstvo postojećih zaposlenih, kao važnog neopipljivog faktora za privlačenje novih zaposlenih. Pored regrutovanja, brend poslodavca, kao percepcija pojedinca o 
kompaniji, odnosno, usaglašenosti PO usklađenosti, je drugi neopipljivi faktor koji može da pojača privlačnost organizacije i zbog toga je predmet istraživanja u ovom radu.

Cilj istraživanja je da se utvrdi da li proces regrutovanja ima uticaj na zadovoljstvo zaposlenih i da li brend poslodavca može da pojača ovu vezu i dodatno poveća zadovoljstvo zaposlenih.

Na osnovu rezultata teorijskih istraživanja, koncipiran je istraživaki model zasnovan na tri hipoteze, čije je testiranje sprovedeno kroz statističku obradu podataka koji su dobijeni originalnim istraživanjem. Prikupljanje podataka izvršeno je primenom anketnog metoda $\mathrm{u}$ formi strukturiranog upitnika. Rezultati regresione analize, koja je korišćenja za testiranje hipoteza, pokazali su postojanje statistički značajnog uticaja između posmatranih varijabli. Rezultati dobijeni kroz ovo istraživanje imaju praktične implikacije kroz utvrđivanje faktora koji mogu pozitivno da utiču na rešavanje problema deficita kandidata za određenje pozicije.

Rad je strukturiran u sedam delova. Nakon uvodnog dela, u drugom delu dat je pregled relevatne literature koja je korišćenja kao osnova za definisanje istraživačkog modela i formulisanje hipoteza. U trećem delu je predstavljenja metodologija istraživanja i u okviru ovog dela predstavljen je način prikupljanja primarnih podataka, statistika uzorka i prikaz statističkih tehnika koje su korišćene za testiranje hipoteza. U četvrtom delu su prikazani rezultati istraživanja kroz prezentaciju rezultata regresione analize koja je korišćenja za testiranje hipoteza. Takođe, u okviru ovog dela rada predstavljeni su rezultati analize pouzdanosti i deskriptivne statističke analize. U petom delu rada je predstavljena diskusija dobijenih rezultata i navedene su praktične implikacije sprovedenog istraživanja. Na kraju rada, dati su zaključci, a pre toga su u posebnom delu predstavljenja ograničenja sprovedenog istraživanja i pravci budućih istraživanja.

\section{PREGLED LITERATURE}

Postoje dve mogućnosti da organizacije zadovolje svoje potrebe za ljudskim resursima, odnosno znanjima, veštinama i talentima:

- interno regrutovanje, kroz sopstveni razvoj talenata, $\mathrm{i}$

- eksterno regrutovanje, putem akvizicije talenata iz okruženja ili drugih organizacija.

Eksterna regrutacija zaposlenih predstavlja jednu od inicijalnih aktivnosti upravljanja ljudskim resursima, u kojoj se definišu preliminarni kriterijumi za ulazak pojedinaca $u$ organizaciju. Regrutacija se može shvatiti kao set aktivnosti, čiji je osnovni cilj da se identifikuju, privuku i angažuju najbolji pojedinci, koji će omogućiti postizanje strategijskih ciljeva preduzeća (Ofori \& Aryeetey, 2011, 48).

U istraživanjima i praksi upravljanja ljudskim resursima, često je osnovni zadatak bio obezbediti realistične informacije o poslu, kako bi kandidati znali šta se od njih očekuje, pri čemu je primat bio na primeni tradicionalnih metoda regrutovanja. U tekućim uslovima poslovanja, samo oglašavanje upražnjenog radnog mesta često nije dovoljno za obezbeđivanje potrebnog broja kvalitetnih kandidata. Konkurencija na tržištu rada zahteva da preduzeće proces regrutacije realizuje pravovremeno, uz upotrebu savremenih tehnoloških rešenja, pri čemu sama regrutacija mora biti vođena marketing strategijom (Slavić, Bjekić i Berber, 2017, 89). Generalno, regrutacija kandidata može biti interna i eksterna, pri čemu preduzeća u praksi primenjuju različite pristupe i koriste različita sredstva za oglašavanje upražnjenog radnog mesta. Osim tradicionalnih načina, posebno je atraktivna i korisna regrutacija putem interneta i društvenih mreža. Internet sajtovi i društvene mreže često kandidatima pružaju brojne informacije $u$ pogledu posla, radnih uslova, organizacione kulture, potrebnih kvalifikacija, omogućavaju razmenu znanja, iskustva i sl.

Proces regrutovanje može imati pozitivan uticaj na različite organizacione ishode. Kvalitetno sproveden proces selekcije ima pozitivan uticaj na povećanje 
stope retencije, organizacione posvećenosti i produktivnosti zaposlenih (Sutanto \& Kurniawan, 2016, 377). Da bi se ostvario odgovarajući nivo zadovoljstva zaposlenih, proces regrutacije potrebno je realizovati tako da zaposleni znaju šta se od njih očekuje na radnom mestu. Poznato je da strategija "slepog oglašavanja", u kojem preduzeće nastoji da sakrije ključne informacije, nije efikasna, budući da zaposleni ne znaju šta se od njih očekuje, pa dati posao ne prihvataju ili brzo napuštaju. Kada se zaposlenom $u$ procesu regrutacije pruže sve relevantne informacije u pogledu toga šta se od njega očekuje, ali i šta on može očekivati od preduzeća, ne dolazi do inflacije očekivanja na radnom mestu, već se lakše izlazi u susret sa zahtevima posla, smanjuje stopa apsentizma, povećava poverenje zaposlenih prema preduzeću, kao i nivo zadovoljstva poslom (Suszko \& Breaugh, 1986, 521). Kao rezultat zadovoljnih zaposlenih, dolazi do unapređenja performansi, efikasnosti, boljih međuljudskih odnosa, smanjenja stope fluktuacije i apsentizma (Inuwa, 2015, 289). Sumirajući prethodno navedeno, a u kontekstu istraživanja koje je obuhvaćeno ovim radom, formulisana je prva hipoteza:

\section{H1: Regrutovanje zaposlenih ima statistički značajan, pozitivan uticaj na njihovo zadovoljstvo.}

Celokupna aktivnost regrutovanja može se podeliti u tri faze: generisanje kandidata, zadržavanje prijavljenih kandidata, i uticaj na donošenje odluka o prihvatanju posla. Zbog toga, potrebno je pravilno upravljati procesom regrutacije, budući da bilo koja aktivnost $\mathrm{u}$ tom procesu može uticati na broj prijavljenih kandidata, njihovu odluku da li će se prijaviti i prihvatiti posao ukoliko im se on ponudi (Breaugh \& Starke, 2000, 407). Veoma bitnu ulogu imaju i izvori upotrebljeni za oglašavanje radnog mesta, kao i imidž preduzeća. Da bi proces regrutacije bio uspešan, odnosno, da bi se privukli i zadržali odgovarajući kandidati sa tržišta rada, potrebno je slediti marketing principe, pogotovo principe brendiranja. Kao jedan od načina da se preduzeće diferencira od drugih i predstavi kao jedinstveno i poželjno mesto za rad jeste i brend poslodavca. Nastao kao rezultat integracije marketinga i upravljanja ljudskim resursima, brend poslodavca predstavlja napor preduzeća u komuniciranju organizacione kulture, sistema, vrednosti i međuljudskih odnosa koji dato radno mesto čine drugačijim od drugih (Singh \& Rokade, 2014, 45).

Implementacija marketinga i principa brendiranja $\mathrm{u}$ disciplini upravljanja ljudskim resursima, dovodi do nastanka brenda poslodavca, koji se može iskoristi kao sredstvo za privlačenje i zadržavanje najboljih kandidata sa tržišta rada. Još od pojave ovog koncepta, 1996, brojni istraživači su nastojali da utvrde ključne karakteristike i faktore koji određeno preduzeće izdvajaju kao jedinstveno i poželjno mesto za rad.

Idejni tvorci ovog koncepta, T. Ambler i S. Barrow (1996, 187), definišu brend poslodavca kao set funkcionalnih, ekonomskih i psiholoških koristi koje su obezbeđene zaposlenjem i koje su karakteristične za preduzeće poslodavca. U pitanju je proces izgradnje slike u svesti kandidata na tržištu rada da je dato preduzeće "poželjno mesto za rad" (Ewing, Pitt, Bussy \& Berthon, 2002, 12). Kao proces izgradnje prepoznatljivog i jedinstvenog identiteta, brend poslodavca predstavlja koncept preduzeća koji ga čini drugačijim od drugih (Backhaus \& Tikoo, 2004, 502). Preduzeće će biti atraktivno, odnosno, dobro mesto za rad, ukoliko nudi dobar balans između života i posla, stimulativne kompenzacije, kvalitetne proizvode i usluge, izazovan zadatak, mogućnost napredovanja, učestvuje u humanitarnim akcijama, omogućuje sticanje dodatnog znanja i ukoliko neguje takvo radno okruženje u kojem postoje dobri međuljudski odnosi (Tanwar \& Prasad, 2016, 4-5).

Kako bi se brend poslodavca izgradio, potrebno je slediti marketing principe. Najpre je potrebno izvršiti internu analizu, odnosno, ispitati postojeći sistem vrednosti, kulturu, zaposlene, politiku upravljanja ljudskim resursima, i konkurentsku poziciju, a zatim, na bazi takvih analiza, utvrditi koji se benefiti mogu ponuditi postojećim i potencijalnim zaposlenima. U narednom koraku se eksternim marketing naporima identifikuju i privlače kandidati koji svojim sposobnostima i sistemom vrednosti odgovaraju preduzeću. Interni marketing je poslednja faza $\mathrm{u}$ izgradnji brenda poslodavca. Aktivnostima internog 
marketinga preduzeće isporučuje zaposlenima obećane vrednosti kako bi se stvorila motivisana radna snaga koja je lojalna preduzeću (Backhaus \& Tikoo, 2004, 502-503; Chhabra \& Sharma, 2014, 51).

Kao rezultat izgradnje brenda poslodavca, nastaju dva veoma bitna ishoda: asocijacije na brend i lojalnost brendu (Backhaus \& Tikoo, 2004, 504). Asocijacije na brend poslodavca predstavljaju ideje koje se javljaju u svesti zaposlenih kada pomisle na određeno preduzeće i zašto je dobro raditi u njemu. Drugim rečima, asocijacije na brend poslodavca oblikuju imidž preduzeća kao poslodavca na tržištu rada. Lojalnost brendu poslodavca predstavlja posvećenost zaposlenih preduzeću. Ukoliko preduzeće ima razvijen brend poslodavca, zaposleni neće tako lako promeniti svoje radno mesto, čak i ukoliko se pojavi neka druga mogućnost zaposlenja (Chhabra \& Sharma, 2014, 50-51).

Kao rezultat stvaranja brenda poslodavca, kompanija lakše i uz niže troškove dolazi do kvalifikovanih zaposlenih, unapređuju se međuljudski odnosi, rastu performanse, povećava stopa retencije, identifikacija sa organizacijom, privrženost preduzeću i samopouzdanje zaposlenih (Chhabra \& Sharma, 2014, 51). Kao i proces regrutacije, brend poslodavca, takođe, ostvaruje uticaj na zadovoljstvo poslom. Rezultati brojnih istraživanja su pokazali da brend poslodavca deluje pozitivno na stepen zadovoljstva poslom zaposlenih (Schlager, Bodderas, Maas \& Cachelin, 2011, 502; Yalim \& Mizrak, 2017, 99; Davies, Mete \& Whelan, 2018, 74). Dobijeni rezultati mogu se objasniti i činjenicom da su faktori zadovoljstva poslom, poput dobrih međuljudskih odnosa, izazovnog posla, stimulativnih kompenzacija i slično, već uključeni u brend poslodavca i obezbeđeni zaposlenima. Navedena istraživanja predstavljaju osnovu za formulisanje druge hipoteze u ovom radu.

H2: Brend poslodavca ima statistički značajan pozitivan uticaj na zadovoljstvo zaposlenih.

Kako brend poslodavca predstavlja efikasno sredstvo za privlačenje kandidata sa tržišta rada, očigledan je njegov značaj u procesu upravljanja ljudskim resursima (Starineca, 2015, 27), pre svega, u procesu regrutacije. Ona preduzeća koja imaju razvijen brend poslodavca izdvajaju se kao prepoznatljiva i poželjna mesta za rad, odnosno, imaju pozitivno izgrađen imidž $u$ javnosti, pa na taj način deluju pozitivno na percepciju kandidata (Gilani \& Cunningham, 2017, 242). Postoje dva bitna elementa ovakvog imidža: stavovi koje zaposleni imaju prema brendu, i percipirane karakteristike, odnosno, koristi koje preduzeće nudi svojim zaposlenima, a na bazi kojih se donosi odluka o prihvatanju posla. Primenom različitih tehnika za privlačenje kandidata, preduzeće može delovati na ove elemente i formirati pozitivnu sliku u javnosti pre nego što započne proces regrutacije. Ovo se može ostvariti aktivnostima sponzorstva, saradnjom sa školama, fakultetima i državnim organima, učestvovanjem u humanitarnim aktivnostima itd (Agrawal \& Swaroop, 2011, 162). Na taj način, unapređuje se proces regrutacije, privlače najbolji kandidati i, istovremeno, štede resursi preduzeća (Khalid \& Tariq, 2015, 358).

Brend poslodavca može da se koristi kao strategijsko sredstvo u procesu regrutacije, koje će omogućiti privlačenje i zadržavanje talenata sa tržišta rada (Franca \& Pahor, 2012, 90). Ukoliko kompanija ima izgrađenu dobru reputaciju u javnosti, proces regrutacije je olakšan, budući da kandidat već ima pozitivan stav prema datoj kompaniji (Saini, Gopal \& Kumari, 2015, 38). U izvesnim slučajevima, kao rezultat takve reputacije, preduzeće je u stanju da privuče one kandidate koji su voljni da rade $u$ datom preduzeću, budući da se njihov sistem vrednosti uklapa u sistem vrednosti preduzeća. Ovo se može objasniti teorijom socijalnog identiteta, prema kojoj ljudi nastoje da budu članovi određene grupe zato što imaju zajedničke karakteristike, vrednosti i stavove (Khalid \& Tariq, 2015, 356).

Veći broj sprovedenih istraživanja je pokazao da preduzeća koja imaju razvijen brend poslodavca lakše realizuju proces regrutacije, privlače i zadržavaju više kvalifikovanih kandidata i ostvaruju brojne druge koristi (Collins \& Stevens, 2002). Kao rezultat implementacije strategije brenda poslodavca u proces regrutacije, zaposleni imaju viši nivo poverenja i osećaju viši stepen identifikacije i privrženosti prema preduzeću, što povećava njihov radni moral. Brojne koristi prisutne su i za poslodavce. Pozitivna slika u 
javnosti omogućava dolazak do najboljih kandidata, razvijaju se nove strategije regrutacije kandidata, raste stopa retencije i povećava zadovoljstvo zaposlenih (Tanwar \& Prasad, 2016, 861). Zadovoljni zaposleni svoje iskustvo prenose drugima i na taj način, pozitivnom usmenom propagandom, dodatno jačaju reputaciju preduzeća na tržištu. Respektujući navedene koristi, formulisana je treća hipoteza ovog istraživanja.

H3: Brend poslodavca je medijator pozitivne veze između regrutovanja zaposlenih i njihovog zadovoljstva.

\section{METODOLOGIJA ISTRAŽIVANJA}

Za identifikaciju uticaja regrutovanja zaposlenih i brenda poslodavca na satisfakciju zaposlenih, sprovedeno je empirijsko istraživanje. Za prikupljanje primarnih podataka, korišćen je anketni metod u formi upitnika koji se sastoji od 25 konstatacija, od kojih se 5 konstatacija odnosi na regrutovanje zaposlenih, sa 10 konstatacija je meren brend poslodavca, dok je nezavisna varijabla, zadovoljstvo zaposlenih, merena sa 10 konstatacija. Anketiranje je sprovedeno kroz direktan kontakt sa ispitanicima, pri čemu im je ostavljeno vreme za popunjavanje upitnika. Prvi deo upitnika sadrži pitanja kojima su prikupljeni deskriptivni podaci o ispitanicima i poslovnim organizacijama koje čine uzorak. Drugi deo upitnika sadrži konstatacije kojima se opservira stanje posmatranih varijabli. Konstatacije su zasnovane na relevantnim prethodnim istraživanjima iz ove oblasti, čime su stvorene pretpostavke za visoku konzistentnost sprovedenog istraživanja ( $\mathrm{Lu}$, While \& Barriball, 2007; Schlager, Bodderas, Maas \& Cachelin, 2011; Peltokorpi \& Jintae Froese, 2016). Stepen slaganja ispitanika sa navedenim konstatacijama iskazivan je putem petostepene Likertove skale.

Koristeći podatke Agencije za privredne registre, nasumično su birane poslovne organizacije i pokrenuta je procedura prikupljanja podataka. Istraživanjem je obuhvaćeno 180 preduzeća, čiji su menadžeri i zaposleni ocenili proces regrutovanja zaposlenih, snagu brenda poslodavca i zadovoljstvo.
Najveći broj kompanija u datom uzorku čine one koje imaju više od 250 zaposlenih, a slede ih kompanije koje imaju između 50 i 250 zaposlenih. Razvoj brenda poslodavca kod preduzeća koja imaju manje od 10 zaposlenih, u praktičnom smislu, nije moguć. Uprkos tome, ove firme nisu isključene iz uzorka iz dva razloga: ove firme, takođe, vode računa o svojoj reputaciji u javnosti; i njihov broj u uzorku je dovoljno mali da ne utiče na rezultate istraživanja. U uzorku je prisutno i skoro $50 \%$ respodenata iz multinacionalnih kompanija ili drugih manjih kompanija koje posluju u Republici Srbiji (RS), čiji su vlasnici iz inostranstva. Njihovo prisustvo u uzorku omogućava bolje sagledavanje konteksta zapošljavanja u RS, jer ove kompanije zapošljavaju značajan broj zaposlenih. Ostali podaci, vezani za statistiku uzorka u pogledu kompanija i ispitanika, dati su u Tabeli 1.

Tabela 1 Struktura uzorka: sumiran pregled

\begin{tabular}{l|cc}
\hline Varijable & $\begin{array}{c}\text { Apsolutna } \\
\text { frekvencija }\end{array}$ & Proporcija (\%) \\
\hline Broj zaposlenih & 1 & $0,6 \%$ \\
2-9 zaposlenih & 35 & $19,4 \%$ \\
10-49 zaposlenih & 64 & $35,6 \%$ \\
50-249 zaposlenih & 80 & $44,4 \%$ \\
Preko 250 zaposlenih & & \\
Osnovna delatnost & 126 & $70,0 \%$ \\
Proizvodnja & 28 & $15,6 \%$ \\
Trgovina & 26 & $14,4 \%$ \\
Usluge & & \\
Tip vlasništva & 90 & $50,0 \%$ \\
Domaći privatni kapital & 88 & $48,9 \%$ \\
Inostrani privatni kapital & 2 & $1,1 \%$ \\
Država & & \\
Pol ispitanika & 81 & $45,0 \%$ \\
Muški & 99 & $55,0 \%$ \\
Ženski & & \\
Nivo obrazovanja & 62 & $34,4 \%$ \\
Srednje obrazovanje & 32 & $17,8 \%$ \\
Više obrazovanje & 86 & $47,8 \%$ \\
Visoko obrazovanje & &
\end{tabular}

Izvor: Autori 
Obrada prikupljenih podataka je sprovedena $\mathrm{u}$ statističkom paketu za društvene nauke, IBM SPSS Statistics, Version 23 (Statistical Package for Social Sciences). Primenom regresione analize, meren je uticaj nezavisne varijable na zavisnu, a medijatorski efekat je testiran kroz rezultate dobijene višestrukom regresionom analizom. U cilju određivanja statističke značajnosti dobijenih rezultata, upotrebljeni su sledeći nivoi poverenja: $\dot{\alpha}=0,05, \dot{\alpha}=0,01$.

\section{REZULTATI ISTRAŽIVANJA}

Kako bi se utvrdila interna konzistentnost navedenih konstatacija, izračunat je Cronbach's alpha koeficijent. Dobijene vrednosti za varijable: regrutovanje zaposlenih, brend poslodavca i zadovoljstvo zaposlenih su 0,908, 0,884, 0,910, respektivno, što ukazuje na visok nivou interne konzistentnosti datih konstatacija. Osim toga, u Tabeli 2 dat je pregled rezultata deskriptivne statističke analize (aritmetička

Tabela 2 Analiza pouzdanosti i deskriptivna statistička analiza

\begin{tabular}{|c|c|c|c|}
\hline \multicolumn{4}{|c|}{ Regrutovanje zaposlenih: Cronbach's alpha koeficijent 0,908 } \\
\hline & Konstatacije & Sredina & Std. dev. \\
\hline RZ1 & Firma troši značajna sredstva za pronalaženje odgovarajućih pojedinaca za slobodna radna mesta. & 3,02 & 1,286 \\
\hline RZ2 & Pronalaženje odgovarajućih pojedinaca za slobodna radna mesta je objektivan i nepristrasan proces. & 3,49 & 1,197 \\
\hline RZ3 & $\begin{array}{l}\text { Za pronalaženje potencijalnih kandidata koriste se različiti izvori kao što su: internet, specijalizovane } \\
\text { agencije, ili stručnjaci za ljudske resurse. }\end{array}$ & 3,57 & 1,260 \\
\hline RZ4 & Firma koristi različite strategije za privlačenje talentovanih pojedinaca. & 3,30 & 1,246 \\
\hline RZ5 & Firma se trudi da angažuje ljude koji imaju sposobnost kreativnog razmišljanja. & 3,39 & 1,378 \\
\hline \multicolumn{4}{|c|}{ Brend poslodavca: Cronbach's alpha koeficijent 0,884 } \\
\hline & Konstatacije & Sredina & Std. dev. \\
\hline BP1 & Firma u kojoj radim se kao poslodavac izdvaja u odnosu na druge firme. & 4,02 & 1,020 \\
\hline $\mathrm{BP}_{2}$ & Za mene je firma u kojoj radim privlačna kao poslodavac. & 3,99 & 1,069 \\
\hline $\mathrm{BP}_{3}$ & Drugi ljudi posmatraju firmu u kojoj radim kao dobro mesto za rad. & 4,12 & 1,029 \\
\hline $\mathrm{BP} 4$ & Poslovi u firmi su plaćeni iznad proseka. & 3,06 & 1,291 \\
\hline BP5 & Posao se obavlja u dobrim radnim uslovima. & 3,79 & 1,075 \\
\hline BP6 & Postoji dobar balans između vremena provedenog na poslu i slobodnog vremena. & 3,50 & 1,275 \\
\hline BP7 & U firmi postoje dobre mogućnosti za napredovanje i usavršavanje. & 3,53 & 1,243 \\
\hline BP8 & Odnosi među zaposlenima su dobri. & 3,90 & 1,088 \\
\hline BP9 & Firma nudi kvalitetne proizvode i/li usluge. & 4,36 & 881 \\
\hline BP10 & Firma ima dobar potencijal za razvoj u narednom periodu. & 4,20 & 1,000 \\
\hline \multicolumn{4}{|c|}{ Zadovoljstvo zaposlenih: Cronbach's alpha koeficijent 0,910 } \\
\hline & Konstatacije & Sredina & Std. dev. \\
\hline $\mathrm{ZZ1}$ & Generalno, zadovoljan sam što radim u ovoj firmi. & 3,88 & 1,035 \\
\hline $\mathrm{ZZ2}$ & Zadovoljan sam radnim okruženjem u kome obavljam posao. & 3,94 & 966 \\
\hline $\mathrm{ZZ3}$ & Uživam u svom poslu. & 3,75 & 1,141 \\
\hline ZZ4 & Adekvatno sam plaćen za posao koji obavljam. & 3,18 & 1,283 \\
\hline ZZ5 & Obavljanje mog sadašnjeg posla nije previše stresno. & 2,97 & 1,256 \\
\hline zZ6 & Posao mi daje osećaj lične ispunjenosti. & 3,49 & 1,289 \\
\hline ZZ7 & U firmi imam sve neophodne uslove i resurse za obavljanje posla. & 3,84 & 1,091 \\
\hline ZZ8 & Zadovoljan sam kolegijalnošću na poslu. & 3,97 & 968 \\
\hline ZZ9 & Zadovoljan sam odnosom sa svojim nadređenima (rukovodiocima, šefovima, direktorima). & 3,94 & 1,051 \\
\hline $\mathrm{ZZ10}$ & Imam osećaj da firma brine o svojim zaposlenima. & 3,60 & 1,198 \\
\hline
\end{tabular}


sredina i standardna devijacija). Na osnovu datih vrednosti, nameće se zaključak da je najveći stepen slaganja ispitanika postignut u slučaju razvijenog brenda poslodavca, budući da su najveće vrednosti aritmetičke sredine identifikovane kod konstatacija koje se odnose na kvalitet proizvoda/usluga datog preduzeća, kao i njegov potencijal za budući razvoj.

U cilju testiranja definisanih hipoteza, sprovedena je regresiona analiza primenom metoda najmanjih kvadrata. Osim toga, kako bi se utvrdio medijatorski efekat, implementiran je postupak koji su razvili R. M. Baron i D. A. Kenny (1986). Navedeni postupak se zasniva na kreiranju nekoliko regresionih modela, koji se odnose na:

- utvrđivanje uticaja nezavisne varijable na varijablu koja predstavlja medijatora,

- utvrđivanje uticaja nezavisne varijable na analiziranu zavisnu varijablu, i

- utvrđivanje uticaja medijatora na zavisnu varijablu.

Poslednji korak predstavlja sprovođenje višestruke regresione analize, koja podrazumeva identifikaciju uticaja nezavisne varijable i medijatora na zavisnu varijablu. Prema R. M. Baron-u i D. A. Kenny-ju (1986, 1177), medijatorski uticaj postoji kada u poslednjem koraku dolazi do smanjenja uticaja nezavisne varijable na zavisnu, ili uticaj nezavisne varijable na zavisnu postaje nesignifikantan.

Shodno objašnjenom postupku, kreirana su četiri regresiona modela. Regresioni model 1 ispituje prirodu i jačinu veze između aktivnosti regrutovanja zaposlenih i kreiranog brenda poslodavca, pri čemu je data zavisna varijabla određena nezavisnom $u$ $50,9 \%$ slučajeva $\left(\mathrm{R}^{2}=0,509\right)$. $\mathrm{U}$ okviru regresionog modela 2, posmatrana je međuzavisnost aktivnosti regrutovanja i zadovoljstva zaposlenih, usled čega dobijena vrednost $R^{2}$ ukazuje na nešto lošiji model $u$ poređenju sa prethodnim $\left(R^{2}=0,460\right)$. Vrednost beta koeficijenta je relevantna na nivou 0,01 , pri čemu pozitivna vrednost ovog koeficijenta upućuje na zaključak da je reč o pozitivnom uticaju regrutovanja zaposlenih na njihovo zadovoljstvo.

Treći regresioni model ima za cilj utvrđivanje veze između brenda poslodavca i zadovoljstva zaposlenih.
Brend poslodavca, kao nezavisna varijabla, određuje posmatranu zavisnu varijablu, zadovoljstvo zaposlenih u $57,7 \%$ slučajeva $\left(\mathrm{R}^{2}=0,577\right)$. Na osnovu prikazanih rezultata i pozitivne vrednosti beta koeficijenta, koja je signifikantna na nivou 0,01, utvrđuje se statistički značajan, pozitivan uticaj kreiranog brenda poslodavca na zadovoljstvo poslom.

Tabela 3 Rezultati regresione analize

\begin{tabular}{|c|c|c|c|c|}
\hline Varijable & $\begin{array}{l}\text { Model 1: } \\
\text { Zavisna } \\
\text { varijabla } \\
\text { brend } \\
\text { poslodavca }\end{array}$ & $\begin{array}{l}\text { Model 2: } \\
\text { Zavisna } \\
\text { varijabla } \\
\text { zadovoljstvo } \\
\text { zaposlenih }\end{array}$ & $\begin{array}{l}\text { Model 3: } \\
\text { Zavisna } \\
\text { varijabla } \\
\text { zadovoljstvo } \\
\text { zaposlenih }\end{array}$ & $\begin{array}{l}\text { Model 4: } \\
\text { Zavisna } \\
\text { varijabla } \\
\text { zadovoljstvo } \\
\text { zaposlenih }\end{array}$ \\
\hline $\begin{array}{l}\text { Regrutovanje } \\
\text { zaposlenih }\end{array}$ & $0,714^{* *}$ & $0,678 * *$ & & $0,277^{* *}$ \\
\hline $\begin{array}{l}\text { Brend } \\
\text { poslodavca }\end{array}$ & & & $0,760 * *$ & $0,562^{* *}$ \\
\hline $\mathrm{R}^{2}$ & 0,509 & 0,460 & 0,577 & 0,615 \\
\hline Adjusted $\mathrm{R}^{2}$ & 0,506 & 0,457 & 0,575 & 0,610 \\
\hline ANOVA F & $181,567^{* *}$ & $149,032^{* *}$ & $238,861 * *$ & $138,900 * *$ \\
\hline
\end{tabular}

Agenda: ${ }^{* *} p<0,01 ;{ }^{*} p<0,05$. U tabeli je prikazan Beta koeficijent.

Izvor: Autori

Četvrti model, predstavljen u Tabeli 3, podrazumeva sprovođenje višestruke regresione analize, koja ima za cilj utvrđivanje uticaja regrutovanja zaposlenih i brenda poslodavca na zavisnu varijablu, zadovoljstvo zaposlenih. U ovom slučaju, 61,5\% varijabiliteta zavisne varijable je objašnjeno obuhvaćenim nezavisnim varijablama. Multikolinearnost ne predstavlja problem, imajući u vidu da je faktor inflacije varijanse manji od 5. Ne postoji ni problem sa autokorelacijom, budući da se Durbin-Watson koeficijent približava vrednosti 2 .

\section{DISKUSIJA I PRAKTIČNE IMPLIKACIJE}

U radu su postavljene tri hipoteze. Prvom hipotezom se nastojalo ukazati na važnost regrutovanja zaposlenih $\mathrm{u}$ cilju generisanja višeg stepena 
zadovoljstva. Rezultati sprovedenih statističkih analiza su pokazali da se način realizovanja regrutovanja zaposlenih pozitivno odražava na nivo njihovog zadovoljstva, što su potvrdili M. Suszko i J. A. Breaugh (1986), i J. Breaugh (2008). Prema tome, hipoteza $\mathrm{H1}$ je potvrđena.

Druga hipoteza je definisana kako bi se identifikovala međuzavisnost razvijenog brenda poslodavca i zadovoljstva zaposlenih. U konkretnom slučaju, izgrađen imidž preduzeća u očima zaposlenih, odnosno, brend poslodavca, pozitivno utiče na zadovoljstvo zaposlenih, kao što su potvrdili $\mathrm{T}$. Schlager et al (2011), G. Davies, M. Mete i S. Whelan (2017), F. Yalim i K. C. Mizrak (2017), čime je hipoteza H2 dokazana.

Treća hipoteza je postavljena kako bi se utvrdio medijatorski uticaj razvijenog brenda poslodavca u slučaju međuzavisnosti procesa regrutovanja i nivoa zadovoljstva zaposlenih. Implementiran postupak, $\mathrm{u}$ vidu kreiranih regresionih modela, pokazuje da $\mathrm{u}$ poslednjem koraku, odnosno, regresionom modelu, dolazi do redukcije u pogledu jačine uticaja regrutovanja na zadovoljstvo zaposlenih. Dakle, jak brend poslodavca predstavlja medijatora uticaja između regrutovanja zaposlenih i njihovog zadovoljstva, zbog čega je hipoteza H3 potvrđena.

Rezultati sprovedenog istraživanja imaju važne praktične implikacije:

- Dobijeni rezultati su potvrda stava da se preko procesa regrutovanja može uticati na željeni nivo zadovoljstva zaposlenih, što preko motivacionih mehanizama treba da dovede do postizanja superiornih performansi.

- Način na koji se sprovode aktivnosti upravljanja ljudskim resursima imaju važan uticaj na kreiranje slike o datom poslodavcu u očima javnosti, odnosno, potencijalnih i postojećih zaposlenih. Prema tome, neophodno je uložiti sistematski napor ka razvoju pozitivnog, jedinstvenog i prepoznatljivog brenda poslodavca, vodeći računa o lojalnosti postojećih zaposlenih datom poslodavcu i njihovoj posvećenosti realizacije postavljenih radnih zadataka.
- Izgrađen brend poslodavca, takođe, utiče na zadovoljstvo zaposlenih tako da ga treba posmatrati kao važan preduslov efektivnog procesa regrutovanja. Ulaganjem u razvoj brenda poslodavca može se povećati zadovoljstvo zaposlenih i, istovremeno, pospešiti privlačenje odgovarajućih kandidata.

- Zadovoljstvo zaposlenih predstavlja preduslov rasta produktivnosti, unapređenja međuljudskih odnosa, kao i smanjenja stope fluktuacije i apsentizma (Inuwa, 2015, 289).

Zato je važno imati integralni pristup prilikom generisanja željenog nivoa zadovoljstva zaposlenih, počevši od: privlačenja potencijalnih kandidata; izbora i zadržavanja najboljeg kandidata; i kreiranja pogodnog ambijenta za rad, sa osvrtom na postizanje balansa između zahteva na radnom mestu i privatnih obaveza, što posledično doprinosi smanjenju stope apsentizma i fluktuacije.

\section{OGRANIČENJA I BUDUĆA ISTRAŽIVANJA}

Uprkos svom doprinosu, istraživanje sprovedeno za potrebe ovog rada ima određeni broj ograničenja, što, ujedno, predstavlja pravce za buduća istraživanja. Najpre, potencijalno ograničenje predstavlja struktura uzorka sa aspekta osnovne delatnosti. Uzorak čine preduzeća koja posluju u okviru sektora proizvodnje, trgovine i usluga, pri čemu svaki od navedenih sektora ima neke specifičnosti, koje se, prevashodno, odnose na izvođenje određenih operacija koje mogu uticati na posmatrane varijable $\mathrm{u}$ istraživanju. Shodno tome, potrebno je izvršiti fokusiranje istraživanja, tako da uzorkom budu obuhvaćena preduzeća, iz određenog sektora. Na ovaj način, izbegla bi se generalizacija stavova, čime bi dobijeni rezultati doprineli unapređenju prakse upravljanja ljudskim resursima u okviru date delatnosti ili sektora, kao i obezbeđenju smernica za razvoj pozitivnog brenda poslodavca uz uvažavanje specifičnosti konkretne delatnosti.

Drugo potencijalno ograničenje se odnosi na veličinu uzorka. U poređenju sa istraživanjima, 
koja su prethodno sprovedena u ovoj oblasti, nameće se potreba povećanja broja anketiranih ispitanika. Ovo ograničenje je posledica relativno nerazvijene poslovne kulture i zatvorenosti preduzeća u tranzicionim ekonomijama, što se, neminovno, odražava na ograničen broj mogućnosti za prikupljanje upitnika i povećanje broja jedinica u uzorku.

Treće ograničenje se odnosi na ispitivanje stavova zaposlenih o načinu sprovođenja regrutacije. Naime, među ispitanicima nije postignuta saglasnost $u$ pogledu ključnog izvora regrutovanja, budući da se u literaturi izdvajaju dva ključna izvora, interno i eksterno regrutovanje. Stoga je potrebno $u$ budućnosti napraviti razliku između navedene dve vrste regrutovanja, fokusiranjem na identifikaciju efektivnosti date vrste, posebno u cilju generiranja višeg stepena zadovoljstva zaposlenih.

Četvrto ograničenje se odnosi na izostanak varijable ili iskaza kojima bi se evaluirao proces regrutovanja ili efekti primenjene strategije regrutacije. S druge strane, u praksi i stručnoj literaturi, sve više preovladava stav da svrha regrutovanja nije privlačenje najboljih kandidata, nego kandidata koji najviše odgovaraju organizaciji, odnosno, onih kandidata koji su najbolje usklađeni sa organizacijom (best fit model). Na taj način, istovremeno se relativizira značaj tradicionalnih merila uspešnosti aktivnosti regrutovanja.

Osim toga, buduća istraživanja treba usmeriti i ka inkorporiranju savremenih dimenzija brenda poslodavca. Na ovaj način bi se stekao uvid u sveukupni potencijal brenda poslodavca kao strategijskog sredstva prilikom sprovođenja aktivnosti regrutovanja i obezbedile preporuke za formulisanje principa izgradnje pozitivnog imidža preduzeća u očima postojećih i potencijalnih zaposlenih. U pogledu utvrđivanja stepena zadovoljstva zaposlenih, preporučuje se upotreba Minnesota upitnika zadovoljstva (Martins \& Proenca, 2012, 4), kao i izračunavanje deskriptivnog indeksa posla (Job Descriptive Index) (Tanwar \& Prasad, 2016, 880). Kreirani instrumenti bi omogućili proveru empirijskih rezultata predstavljenih $\mathrm{u}$ radu, kao i detaljnu analizu različitih aspekata zadovoljstva poslom.

\section{ZAKLJUČAK}

Rezultati regresione analize su pokazali da regrutovanje zaposlenih ima statistički značajan uticaj na njihovo zadovoljstvo, isto kao i brend poslodavca, čime se potvrđene hipoteze H1 i H2. Takođe, kroz model višestruke regresione analize, $u$ radu je potvrđena medijatorska uloga brenda poslodavca, čime je dokazana hipoteza H3. U praktičnom smislu, rezultati istraživanja pokazuju da se kroz usmerevanje procesa regrutovanja zaposlenih može uticati na važne organizacione ishode, kao što je to, na primer, zadovoljstvo zaposlenih. Pored toga, predstavljanje kompanije u javnosti kao poželjnog poslodavca, kroz razvoj brenda poslodavca, takođe, doprinosi povećanju zadovoljstva zaposlenih. Generalni zaključak je da navedene varijable, regrutovanje i brend poslodavca, mogu pozitivno uticati na zadovoljstvo zaposlenih, što je važan preduslov za kreiranje slike o kompaniji kao privlačnom mestu za rad. Na taj način, povećava se verovatnoća privlačenja novih talenata $\mathrm{u}$ organizaciju i potencijalno rešava problem postojećeg deficita talenata i veština na lokalnom i globalnom tržištu radne snage. Ulažući sredstva u određene dimenzije brenda poslodavca kompanije zapravo rade na usaglašavanju PO usklađenosti, kao važnom preduslovu za privlačenje i zadržavanje pojedinaca u okviru jedne kompanije.

Definisanjem načina sprovođenja procesa regrutovanja, može se uticati na ponašanje zaposlenih $\mathrm{u}$ organizaciji $\mathrm{i}$ na njihovo zadovoljstvo poslom, što je potvrđeno $u$ radu. Medijatorski uticaj brenda poslodavca, koji je utvrđen ovim istraživanjem, $\mathrm{u}$ praktičnom smislu pokazuje da ulaganje u brend poslodavca povećava stepen usaglašenosti pojedinaca sa predselekcionim kriterijumima koji su sadržani $\mathrm{u}$ regrutovanju zaposlenih i da povećava stepen identifikacije pojedinaca sa kompanijom. S druge strane, priliv potencijalnih kandidata $\mathrm{u}$ aktivnosti regrutovanja može se, u značajnoj meri, redukovati kroz proces selekcije, zbog čega je potrebno $u$ buduća istraživanji uključiti i proces selekcije, iako se u situaciji kada postoji značajan deficit ljudskih resursa na tržištu radne snage selekcioni kriterijumi modifikuju i prilagođavaju tekućim okolnostima. 


\section{REFERENCE}

Agrawal, R. K., \& Swaroop, P. (2011). Buliding employer brand image through early recruitment practices: a study in Indian context. Asia - Pacific Business Review, 7(2), 160-169. doi:10.1177/097324701100700215

Ambler, T., \& Barrow, S. (1996). The employer brand. The Journal of Brand Management, 4(3), 185-206. doi:10.1057/ bm.1996.42

Backhaus, K., \& Tikoo, S. (2004). Conceptualizing and researching employer branding. Career Development International, 9(5), 501-517. doi:10.1108/13620430410550754

Baron, R. M., \& Kenny, D. A. (1986). The moderator-mediator variable distinction in social psychological research: Conceptual, strategic, and statistical considerations. Journal of personality and social psychology, 51(6), 1173-1182. doi. org/10.1037/0022-3514.51.6.1173

Boston Consulting Group. (2018). Decoding Global Talent. Boston, US: Retrieved June 25, 2018, from https://www.bcg. com/publications/2018/decoding-global-talent.aspx

Breaugh, J. A. (2008). Employee recruitment: Current knowledge and important areas for future research. Human Resource Management Review, 18(3), 103-118. doi:10.1016/j. hrmr.2008.07.003

Breaugh, J. A., \& Starke, M. (2000). Research on employee recruitment: So many studies so many remaining questions. Journal of Management, 26(3), 405-434. doi:10.1177/014920630002600303

Chhabra, L. N., \& Sharma, S. (2014). Employer branding: Strategy for improving employer attractiveness. International Journal of Organisational Analysis, 22(1), 48-60. doi:10.1108/IJOA-09-2011-0513

Collins, C. J., \& Stevens, C. K. (2002). The relationship between early recruitment - related activities and the application decision of new labor - market entrants: A brand equity approach to recruitment. Journal of Applied Psychology, 87(6), $1121-1133$

Davies, G., Mete, M., \& Whelan, S. (2018). When employer brand image aids employee satisfaction and engagement. Journal of Organizational Effectiveness: People and Performance, 5(1), 64-80. doi:10.1108/JOEPP-03-2017-0028

De Smet, A., \& Gagnon, C. (2018). Organizing for the age of urgency. McKinsey Quarterly, January 2018. Retrieved June 25, 2018, from https://www.mckinsey.com/businessfunctions/organization/our-insights/organizing-for-theage-of-urgency
Ewing, M. T., Pitt, L. F., Bussy, N. M., \& Berthon, P. (2002). Employment branding in the knowledge economy. International Journal of Advertising, 21(1), 3-22. doi:10.1080/0 2650487.2002.11104914

Franca, V., \& Pahor, M. (2012). The strength of the employer brand: Influences and implications for recruiting. Journal of Marketing \& Management, 3(1), 78-122.

Gilani, H., \& Cunningham, L. (2017). Employer branding and its influence on employee retention: a literature review. The Marketing Review, 17(2), 239-256. doi:10.1362/14693471 7X14909733966209

Greguras, G. J., \& Diefendorff, J. M. (2009). Different fits satisfy different needs: Linking person-environment fit to employee commitment and performance using selfdetermination theory. Journal of Applied Psychology, 94(2), 465-477. doi:10.1037/a0014068

Inuwa, M. (2015). The impact of job satisfaction, job attitude and equity on employee performance. The International Journal of Business and Management, 3(5), 288-293.

Khalid, S., \& Tariq, S. (2015). Impact of employer brand on selection and recruitment process. Pakistan Economic and Social Review, 53(2), 351-372.

Lanvin, B., \& Evans, P. (2017). The Global Talent Competitiveness Index. Fontainebleau, France: INSEAD Business School, Adecco Group and Human Capital Leadership Institute.

Lu, H., While, A. E., \& Barriball, K. L. (2007). Job satisfaction and its related factors: A questionnaire survey of hospital nurses in Mainland China. International Journal of Nursing Studies, 44(4), 574-588. doi:10.1016/j.ijnurstu.2006.07.007

ManpowerGroup. (2018). Talent Shortage Survey: Solving the Talent Shortage: Build, Buy, Borrow and Bridge. Employment Outlook Survey. Milwaukee, US: Retrieved June 25, 2018, from https://go.manpowergroup.com/talent-shortage-2018

Martins, H., \& Proença, T. (2012). Minnesota Satisfaction Questionnaire-Psychometric properties and validation in a population of Portuguese hospital workers. FEP JournalEconomics \& Management: Working Paper, 471(1), 1-23.

Ofori, D., \& Aryeetey, M. (2011). Recruitment and selection practices in small and medium enterprises: Perspectives from Ghana. International Journal of Business Administration, 2(3), 45-60. doi:10.5430/ijba.v2n3p45

Peltokorpi, V., \& Jintae Froese, F. (2016). Recruitment source practices in foreign and local firms: A comparative study in Japan. Asia Pacific Journal of Human Resources, 54(4), 421-444. doi:10.1111/1744-7941.12076 
Saini, G. K., Gopal, A., \& Kumari, N. (2015). Employer brand and job application decisions: Insights from the best employers. Management and Labor Studies, 40(1-2), 34-51. doi:10.1177/0258042X15601532

Schlager, T., Bodderas, M., Maas, P., \& Cachelin, J. L. (2011). The influence of the employer brand on employee attitudes relevant for service branding: An empirical investigation. Journal of Services Marketing 25(7), 497-508. doi:10.1108/08876041111173624

Sekiguchi, T. (2007). A contingency perspective of the importance of PJ fit and PO fit in employee selection. Journal of Managerial Psychology, 22(2), 118-131. doi:10.1108/02683940710726384

Singh, M., \& Rokade, V. (2014). Employer branding: A strategic dimension for employee retention. Journal of Marketing and Consumer Research, 5, 44-49.

Slavić, A., Bjekić, R. i Berber, N. (2017). Uloga interneta i društvenih mreža u procesu regrutacije i selekcije. U A. Grubor (Ur.). Strategijski menadžment $i$ sistemi podrške odlučivanju u strategijskom menadžmentu - SM2017 (str. 88-96). Subotica, Republika Srbija: Ekonomski fakultet u Subotici Univerziteta u Novom Sadu.
Starineca, O. (2015). Employer brand role in HR recruitment and selection. Economics and Business, 27(1), 58-63. doi:10.1515/eb-2015-0009

Suszko, M. K., \& Breaugh, J. A. (1986). The effects of realist job previews on applicant self-selection and employee turnover, satisfaction, and coping ability. Journal of Management, 12(4), 512-523. doi:10.1177/014920638601200406

Sutanto, E. M., \& Kurniawan, M. (2016). The impact of recruitment, employee retention and labor relations to employee performance on batik industry in Solo city, Indonesia. International Journal of Business and Society, 17(2), 375-390.

Tanwar, K., \& Prasad, A. (2016). The effect of employer brand dimensions on job satisfaction: Gender as a moderator. Management Decision, 54(4), 854-886. doi: 10.1108/MD-082015-0343

Yalim, F., \& Mizrak, K. C. (2017). A field study on the relationship between employer brand and employee satisfaction. International Review of Management and Marketing, 7(2), 92-103.

Primljeno 9. jula 2018, nakon revizije, prihvaćeno za publikovanje 22. avgusta 2018. Elektronska verzija objavljena 27. avgusta 2018.

Marko Slavković je docent na Ekonomskom fakultetu Univerziteta u Kragujevcu, gde je i doktorirao, iz oblasti strategijskog upravljanja ljudskim resursima. Izvodi nastavu na osnovnim, master i doktorskim akademskim studijama. Oblast njegovog naučno-istraživačkog interesovanja je menadžment i strategija upravljanja ljudskim resursima.

Goran Pavlović je student doktorskih studija Ekonomskog fakultetu Univerziteta u Kragujevcu. Oblasti njegovog istraživačkog interesovanja su: upravljanje ljudskim resursima, organizaciono ponašanje i konkurentska prednost.

Marijana Simić je istraživač-pripravnik na Ekonomskom fakultetu Univerziteta u Kragujevcu, iz uže naučne oblasti Poslovna ekonomija. Student je doktorskih akademskih studija Ekonomskog fakulteta Univerziteta u Kragujevcu. Oblasti njenog istraživačkog interesovanja su: menadžment ljudskim resursima, preduzetništvo i organizaciono ponašanje. 


\title{
EMPLOYEE RECRUITMENT AND ITS RELATIONSHIP WITH EMPLOYEE SATISFACTION: VERIFYING THE MEDIATING ROLE OF THE EMPLOYER BRAND
}

\author{
Marko Slavkovic ${ }^{* 1}$, Goran Pavlovic ${ }^{2}$ and Marijana Simic ${ }^{2}$ \\ ${ }^{1}$ Faculty of Economics, University of Kragujevac, Kragujevac, The Republic of Serbia \\ ${ }^{2} \mathrm{PhD}$ student at the Faculty of Economics, University of Kragujevac, Kragujevac, The Republic of \\ Serbia
}

The transformation of a capital-intensive to knowledge-driven economy has marked the beginning of a new epoch in business doing. Carrying out business activities in an extremely dynamic environment has greatly reduced the importance of traditional concepts and techniques, which is the reason why the focus has shifted to human resources and their management. Accordingly, a company should attract, retain and motivate its employees in order to ensure a high level of their satisfaction by ensuring the achievement of strategic goals. A possible direction of achieving the desired position is based on the development of the employer brand. Therefore, the aim of this paper is to determine the impact of practice in conducting employee recruitment activities on their satisfaction, as well as the influence of the employer brand as a mediator on the identified relationship between the recruitment and satisfaction of employees in Serbia. The results of the conducted empirical research study have proven the existence of a statistically significant positive influence of employee recruitment on satisfaction, while the mediating influence of the employer brand has also been fully confirmed.

Keywords: recruitment, employee satisfaction, employer brand, talents, fit model

JEL Classification: M12, M39, M51 